\title{
Rick Strelan
}

Paul, Artemis, and the Jews in Ephesus

$W$
$\mathrm{DE}$
$\mathrm{G}$ 


\title{
Beihefte zur Zeitschrift für die neutestamentliche Wissenschaft \\ und die Kunde der älteren Kirche
}

\author{
Herausgegeben von \\ Erich Gräßer
}

\author{
Band 80
}

Walter de Gruyter - Berlin · New York 1996 
Rick Strelan

\section{Paul, Artemis, and the Jews in Ephesus}

Walter de Gruyter - Berlin - New York 1996 
@ Printed on acid-free paper which falls within the guidelines of the ANSI to ensure permanence and durability.

Die Deutsche Bibliothek - Cataloging-in-Publication Data

[Zeitschrift für die neutestamentliche Wissenschaft und die Kunde der älteren Kirche / Beihefte]

Beihefte zur Zeitschrift für die neutestamentliche Wissenschaft und die Kunde der älteren Kirche. - Berlin ; New York : de Gruyter.

Früher Schriftenreihe

Reihe Beihefte zu: Zeitschrift für die neutestamentliche Wissen-

schaft und die Kunde der älteren Kirche

NE: HST

Bd. 80. Strelan, Rick: Paul, Artemis, and the Jews in Ephesus. - 1996

Strelan, Rick:

Paul, Artemis, and the Jews in Ephesus / Rick Strelan. - Berlin; New York : de Gruyter, 1996

(Beihefte zur Zeitschrift für die neutestamentliche Wissenschaft und die Kunde der älteren Kirche ; Bd. 80)

Zugl.: Queensland, Univ., Diss., 1995

ISBN 3-11-015020-4

\section{ISSN 0171-6441}

(C) Copyright 1996 by Walter de Gruyter \& Co., D-10785 Berlin

All rights reserved, including those of translation into foreign languages. No part of this book may be reproduced or transmitted in any form or by any means, electronic or mechanical, including photocopy, recording or any information storage and retrieval system, without permission in writing from the publisher.

$$
\text { Printed in Germany }
$$

Printing: Werner Hildebrand, Berlin

Binding: Lüderitz \& Bauer-GmbH, Berlin 
Dedicated with gratitude to MICHAEL LATTKE

teacher and scholar 
